\title{
Aplikasi Polyhalite sebagai Pengganti ZK dan Pengaruhnya terhadap Kadar K, Mg, dan S Daun, Produksi, dan Mutu Buah Jeruk Siam
}

\section{Application of Polyhalite as a Substitute for ZK and Effects on Levels of $\mathrm{K}, \mathrm{Mg}$, and S Leaves, Production and Quality of Siamese Citrus Fruits}

\author{
Sutopo, Titistyas Gusti Aji \\ Indonesian Citrus and Subtropical Fruit Research Institute, Batu, Indonesia \\ *Corresponding author: titistyasgusti@pertanian.go.id
}

Received: September 9, 2020; Accepted: September 28, 2020; Published: October 1, 2020

\begin{abstract}
As a natural mineral that contains several macro elements, polyhalite (K2Ca2Mg (SO4) 4H2O) has good potential as a fertilizer. This study aims to study the effect of polyhalite on branch growth, leaf nutrition ( $\mathrm{K}, \mathrm{Mg}$ and $\mathrm{S})$, chlorophyll index, harvest weight, fruit quality, and the effective dose of Siam citrus. A 4-year-old Siam citrus planted on vertisol soil was treated with 6 fertilizer treatments: $625 ; 1,000 ; 1,375 ; 1,750 ; 2.125 \mathrm{~kg}$ polyhalite and $625 \mathrm{~kg}$ $\mathrm{ZK} /$ hectare/year. The experiment using a randomized block design was repeated 3 times. The results showed that the application of polyhalite at the same $\mathrm{K}_{2} \mathrm{O}$ dose as $\mathrm{ZK}$ increased leaf $\mathrm{Mg}$ content, chlorophyll index and total juice solids significantly. Polyhalite application of $1,750 \mathrm{~kg} / \mathrm{hectare}(2.8 \mathrm{~kg} / \mathrm{tree})$ is an effective dose for mature Siam citrus in vertisol with moderate $\mathrm{K}$ status and high $\mathrm{Ca}$ and $\mathrm{Mg}$ status.
\end{abstract}

Key words: chlorophyll index, leaves plant growth, nutrient

Cite this as: Sutopo, \& Aji, T. G. (2020). Aplikasi Polyhalite sebagai Pengganti ZK dan Pengaruhnya terhadap Kadar K, Mg, dan S Daun, Produksi, dan Mutu Buah Jeruk Siam. Agrosains : Jurnal Penelitian Agronomi 22(2): 114-118. DOI: http://dx.doi.org/10.20961/agsjpa.v22i2.44249

\section{PENDAHULUAN}

Sekitar $60 \%$ populasi jeruk komersial yang dikembangkan di Indonesia adalah jenis jeruk Siam (Citrus nobilis) karena memiliki adaptasi luas (dataran rendah - tinggi), rajin berbuah dengan produktivitas tinggi, dan cita rasanya lebih digemari oleh sebagian besar masyarakat dibandingkan dengan jeruk keprok (Citrus reticulata). Kebanyakan buah jeruk ini dikonsumsi langsung sebagai buah segar, dan sebagian kecil digunakan untuk minuman di rumah makan sehingga kualitas eksternal maupun internal buah menentukan penerimaan konsumen dan harga di pasar.

Jeruk Siam sangat responsif terhadap perubahan kesuburah tanah sehingga pertumbuhan, volume hasil buah dan mutunya sangat dipengaruhi oleh pasokan pupuk (Boughalleb et al., 2011; Obreza et al., 2008; Paramasivam et al., 2000). Ketika tanaman memasuki usia produktif, buah merupakan komponen utama dibandingkan dengan komponen lainnya. Menurut Mattos Jr. et al., (2003), bobot kering buah jeruk mencapai $30,3 \%$, lalu diikuti oleh akar $=27,8 \%$, ranting $=26,1 \%$, daun $=9,7 \%$, dan batang $=6,3 \%$. Lebih lanjut Sutopo et al., (2004) melaporkan bahwa setiap $100 \mathrm{~kg}$ bobot segar buah jeruk Siam mengandung $1,16 \mathrm{~kg} \mathrm{~N}$; 0,30 kg P; 0,19 kg K; 0,37 kg Ca; dan 0,002 kg Mg.

Untuk mencapai hasil buah yang optimal, tanaman tidak hanya membutuhkan pasokan yang cukup dari unsur hara makro primer $\mathrm{N}, \mathrm{P}$ dan $\mathrm{K}$, melainkan juga unsur hara makro sekunder $\mathrm{Ca}, \mathrm{Mg}, \mathrm{S}$, serta unsur hara mikro $\mathrm{Fe}, \mathrm{Mn}, \mathrm{Zn}, \mathrm{Cu}, \mathrm{B}, \mathrm{Mo}, \mathrm{Cl}, \mathrm{Ni}$ (Moss \& Higgins, 1974; Singh et al., 2019; Zekri \& Obreza, 2002). Kalium dibutuhkan tanaman untuk melaksanakan beberapa fungsi fisiologis dasar, seperti pembentukan gula dan pati, sintesis protein, dan pembelahan sel. Unsur ini juga membantu meregulasi asupan karbondioksida untuk tanaman dengan mengatur pembukaan dan penutupan stomata. Apabila terjadi defisiensi kalium, tingkat fotosintesis akan menurun dan dapat berakibat pada penurunan hasil dan kualitas buah. Selain penting untuk pembentukan buah, kalium juga dapat meningkatkan ukuran, rasa, dan warna buah jeruk (Koo, 2015; Obreza, 2003; Tränkner et al., 2018; Zekri \& Obreza, 2013b). Magnesium adalah konstituen penting penyusun klorofil, yang terdapat di pusat molekul kloroplas. Unsur ini terlibat dalam fotosintensis dan berperan penting sebagai aktivator enzim, metabolisme karbohidrat, serta sintesis asam nukleat. Aktivitas partisi atau transpor karbohidrat dari organ source ke sink juga dipengaruhi oleh magnesium. Defisiensi magnesium dapat berakibat pada penurunan hasil dan kualitas buah, terutama penurunan padatan terlarut, keasaman, dan kandungan vitamin C pada jus buah (Farhat et al., 2016; Moss \& Higgins, 1974; Quaggio et al., 1992; Zekri \& Obreza, 2013a, 2003). Belerang (S) adalah konstituen yang penting pada berbagai protein, vitamin, dan beberapa hormon tumbuhan. Unsur ini memegang peran dalam sintesis protein dan asam amino, metabolisme karbohidrat, serta produksi klorofil. Laju fotosintesis 
bersih, laju fotorespirasi, dan kandungan protein daun jeruk manis menurun pada kondisi kekurangan belerang. Defisiensi belerang telah menjadi hal yang umum akibat semakin maraknya penggunaan pupuk dengan kandungan $\mathrm{N}$ yang tinggi namun $\mathrm{S}$ yang rendah, seperti amonium nitrat, kalium nitrat, urea, superfosfat pekat, monoamonium fosfat (MAP), dan diamonium fosfat (DAP) (Chen \& Wang, 2006; Zekri \& Obreza, 2019, 2003).

Suplai unsur hara makro dan mikro melalui aplikasi pupuk penting bagi pertumbuhan dan perkembangan tanaman. Kebanyakan jenis pupuk di pasar adalah pupuk tunggal sehingga aplikasinya perlu dicampur dengan pupuk lain. Meskipun macam pupuk majemuk jumlahnya cenderung bertambah, sebagian besar hanya mengandung unsur makro primer (NPK). Polyhalite, mineral alami dengan formula kimia $\mathrm{K}_{2} \mathrm{SO}_{4} \cdot \mathrm{MgSO}_{4} .2 \mathrm{CaSO}_{4} .2 \mathrm{H}_{2} \mathrm{O}$, mengandung beberapa unsur hara makro esensial memiliki potensi dikembangkan sebagai pupuk untuk menggantikan pupuk $\mathrm{K}$ ( $\mathrm{ZK}$ atau $\mathrm{KCl})$ yang harganya relatif mahal. Hasil analisis kimia kandungan pupuk menunjukkan bahwa polyhalite mengandung lebih dari 10 unsur hara yang penting bagi pertumbuhan dan perkembangan tanaman (Barbier et al., 2017). Unsur K, Ca, Mg, dan S pada Polyhalite juga mudah tersedia bagi tanaman, baik pada tanah lempung maupun tanah berpasir (Dal Molin et al., 2019; Yermiyahu et al., 2017).

Tu (2018) melaporkan bahwa aplikasi polyhalite pada tanaman teh di tanah basaltik (rhodic ferrasols) di Lam Dong, Vietnam dapat memasok $\mathrm{K}, \mathrm{Ca}, \mathrm{Mg}$ dan $\mathrm{S}$ yang dibutuhkan tanaman, meningkatkan kepadatan, berat dan ukuran tunas teh, sehingga meningkatkan produktivitas teh. Kandungan $\mathrm{K}, \mathrm{Ca}, \mathrm{Mg}$, dan $\mathrm{S}$ pada daun teh meningkat berturut-turut hingga 18\%, 38\%, $60 \%$, dan $54 \%$ dibandingkan tanaman yang diberi pupuk $\mathrm{KCl}$ dengan kadar $\mathrm{K}$ yang sama. Hal ini diduga akibat kelarutan polyhalite yang lebih lambat dibandingkan dengan garam sulfat dari $\mathrm{K}, \mathrm{Ca}$, dan $\mathrm{Mg}$, sehingga membuat unsur hara tersedia secara bertahap dan lebih lama bagi tanaman (Yermiyahu et al., 2017). Hasil penelitian Suntari et al. (2020) menunjukkan bahwa aplikasi $50 \%$ polyhalite $+50 \% \mathrm{KCl}(642 \mathrm{~kg} / \mathrm{ha}$ polyhalite + $150 \mathrm{~kg} / \mathrm{ha} \mathrm{KCl}$ ) meningkatkan tinggi tanaman dan jumlah daun benih jeruk pamelo secara nyata dibandingkan dengan $\mathrm{KCl}$.

Penelitian mengenai aplikasi polyhalite pada tanaman jeruk produktif masih jarang/belum ditemukan. Informasi ini penting sebagai referensi bahan lain pemasok unsur $\mathrm{K}, \mathrm{Mg}$, dan $\mathrm{S}$ yang lebih murah dan ramah lingkungan. Oleh karena itu, penelitian ini bertujuan mengevaluasi dosis polyhalite sebagai alternatif pengganti pupuk ZK dan pengaruhnya terhadap kadar $\mathrm{K}, \mathrm{Mg}$ dan $\mathrm{S}$, dan produksi serta mutu buah jeruk Siam.

\section{BAHAN DAN METODE}

Percobaan dilakukan di daerah dataran rendah sentra produksi jeruk Siam, Dusun Tamansuruh, Desa Bangorejo, Kecamatan Bangorejo, Kabupaten Banyuwangi, Jawa Timur mulai Oktober 2018 - Oktober 2019. Analisis kualitas buah dilakukan di Laboratorium Ekofisiologi, Balai Penelitian Tanaman Jeruk dan Buah Subtropika. Lokasi percobaan merupakan lahan basah (beririgasi teknis), dengan jenis tanah Grumosol (Vertisol), bertekstur liat, memiliki struktur keras di bagian atas dan gumpal di bagian bawah, dengan konsistensi teguh atau keras apabila kering. Kemasaman tanahnya adalah agak masam, kandungan karbon organik dan nitrogen total rendah, dan $\mathrm{P}$ tersedia sangat tinggi. Basa-basa dapat ditukar sangat tinggi dan didominasi oleh Ca dan Mg, kapasitas tukar kation (KTK) sedang dan kejenuhan basa sangat tinggi (Tabel 1).

Tabel 1. Karakteristik Vertisol Lokasi Percobaan di Banyuwangi

\begin{tabular}{lcc}
\hline \multicolumn{1}{c}{ Karakter } & Nilai & Kriteria *) \\
\hline $\mathrm{pH} \mathrm{H} \mathrm{H}_{2} \mathrm{O}$ & 5,9 & Agak masam \\
C-organik (\%) & 1,75 & Rendah \\
N-total (\%) & 0,13 & Rendah \\
C/N Rasio & 13 & \\
P tersedia Olsen & 194 & Sangat tinggi \\
(ppm) & 24,17 & Sedang \\
KTK (me/100 g) & 0,35 & Sedang \\
K-dd (me/100 g) & 12,58 & Tinggi \\
Ca-dd (me/100 g) & 5,52 & Tinggi \\
Mg-dd (me/100 g) & 0,34 & Sedang \\
Na-dd (me/100 g) & 78 & Sangat tinggi \\
Kejenuhan Basa (\% & 7 & Liat \\
Tekstur: & & \\
Pasir (\%) & 29 & \\
Debu (\%) & 64 & \\
Liat (\%) & 7 &
\end{tabular}

Keterangan: *) Berdasarkan penilaian hasil analisis tanah Balai Penelitian Tanah (2009)

Bahan yang digunakan yaitu tanaman jeruk Siam (Citrus nobilis) umur 4 tahun yang diokulasi pada batang bawah Japansche Citroen (JC), ditanam menggunakan jarak $4 \mathrm{~m}$ x $4 \mathrm{~m}$ (625 pohon/hektar). Pupuk yang digunakan meliputi urea $(46 \% \mathrm{~N})$, SP36 $\left(36 \% \mathrm{P}_{2} \mathrm{O}_{5}\right)$, $\mathrm{ZK}$ $\left(50 \% \mathrm{~K}_{2} \mathrm{O}\right)$ dan polyhalite $\left(48 \% \mathrm{SO}_{3}, 14 \% \mathrm{~K}_{2} \mathrm{O}, 6 \% \mathrm{MgO}\right.$ and $17 \% \mathrm{CaO})$.

Percobaan menggunakan Rancangan Acak Kelompok terdiri atas 6 perlakuan pupuk, yaitu meliputi aplikasi pupuk ZK (kontrol) dan 5 dosis pupuk polyhalite (Tabel 2). Setiap perlakuan terdiri atas 10 pohon dan diulang sebanyak 3 kali, sehingga total tanaman yang diamati berjumlah 180 tanaman.

Tabel 2. Perlakuan Percobaan

\begin{tabular}{|c|c|}
\hline T1 & $\begin{array}{l}625 \mathrm{~kg} \mathrm{ZK}+1.875 \mathrm{~kg} \text { urea }+1.562,5 \mathrm{~kg} \\
\text { SP36/hektar/satu musim panen. }\end{array}$ \\
\hline T2 & $\begin{array}{l}625 \mathrm{~kg} \text { Polyhalite }+1.875 \mathrm{~kg} \text { urea }+1.562,5 \\
\text { kg SP36/hektar/satu musim panen. }\end{array}$ \\
\hline T3 & $\begin{array}{l}1.000 \mathrm{~kg} \text { Polyhalite }+1.875 \mathrm{~kg} \text { urea }+1.562,5 \\
\mathrm{~kg} \text { SP36/hektar/satu musim panen. }\end{array}$ \\
\hline T4 & $\begin{array}{l}1.375 \mathrm{~kg} \text { Polyhalite }+1.875 \mathrm{~kg} \text { urea }+1.562,5 \\
\mathrm{~kg} \mathrm{SP36/hektar/satu} \mathrm{musim} \mathrm{panen.}\end{array}$ \\
\hline T5 & $\begin{array}{l}1.750 \mathrm{~kg} \text { Polyhalite }+1.875 \mathrm{~kg} \text { urea }+ \\
1.562,5 \mathrm{~kg} \text { SP36/hektar/satu musim panen. }\end{array}$ \\
\hline T6 & $\begin{array}{l}2.125 \mathrm{~kg} \text { Polyhalite }+1.875 \mathrm{~kg} \text { urea }+1.562,5 \\
\mathrm{~kg} \text { SP36/hektar/satu musim panen. }\end{array}$ \\
\hline
\end{tabular}

Untuk memenuhi kebutuhan $\mathrm{N}$ dan $\mathrm{P}$, semua tanaman diberi $1,875 \mathrm{~kg}$ urea $+1.562,5 \mathrm{~kg}$ SP36/hektar/tahun. Dosis pupuk dibagi tiga untuk diaplikasikan 3 kali, yaitu bulan Desember 2018, Februari dan Maret 2019. Pemeliharaan tanaman yang dilakukan meliputi pemangkasan cabang yang dilakukan 
setelah panen, pewiwilan tunas air dilakukan setiap hari, pengendalian gulma, pengairan pada musim kemarau dua bulan sekali, dan pengendalian hama dan penyakit didasarkan pada OPT yang menyerang. Parameter yang diamati meliputi:

a. Pertambahan panjang cabang: dihitung dari rata-rata pertambahan cabang lateral (4 arah mata angin) selama satu tahun.

b. Kadar K, Mg, S daun: sampel daun dikumpulkan dari daun sehat yang tidak mendukung bunga/buah, umur daun sekitar 7 bulan. Analisis dilakukan di Laboratorium Ilmu Tanah Balai Penelitian Tanah dan Agroklimat, Bogor.

c. Jumlah buah per pohon dihitung pada saat panen.

d. Diameter buah diukur pada saat buah siap dipanen menggunakan alat jangka sorong.

e. Bobot panen diukur bersama panen di lapangan menggunakan metode gravimetri.

f. Kandungan sari buah dihitung berdasarkan bobot sari buah dibagi dengan total bobot buah kali $100 \%$.

g. Kandungan total padatan terlarut diukur menggunakan digital refractometer.

h. Kandungan asam diukur dengan metode titrasi.

Seluruh data yang diperoleh diuji dengan uji $F$. Apabila hasil uji $\mathrm{F}$ menunjukkan bahwa perlakuan memberikan pengaruh yang signifikan, maka dilanjutkan dengan Uji Jarak Berganda Duncan (Duncan Multiple Range Test) dengan taraf kepercayaan 95\%.

\section{HASIL DAN PEMBAHASAN \\ Pertumbuhan Cabang, Kadar K, Mg, S dan Indeks Klorofil Daun}

Berbeda dengan tanaman muda, pertumbuhan vegetatif tanaman jeruk produktif seperti tinggi tanaman dan lebar tajuk bukan menjadi parameter yang baik untuk mengetahui respon tanaman terhadap aplikasi pupuk karena pada saat menjelang panen cabangcabang pendukung buah merunduk akibat terbebani buah sehingga tinggi tanaman dan lebar tajuk bisa berkurang dari sebelumnya. Oleh karena itu, pertambahan panjang cabang lateral merupakan satusatunya parameter pertumbuhan yang diukur sebagai pewakil respon pertumbuhan vegetatif.

Pertambahan panjang cabang lateral jeruk Siam produktif tidak dipengaruhi oleh aplikasi polihalyte (T2 T6) dan ZK (T1). Dalam 1 tahun, panjang cabang lateral bertambah antara $41-57 \mathrm{~cm}$ (Tabel 3). Hal ini menunjukan bahwa kalium (K) bukan menjadi faktor pembatas pertumbuhan vegetatif pada tanaman jeruk Siam produktif di Vertisol dengan status $\mathrm{K}$ dapat ditukar sedang. Kemungkinan lain yaitu sebagian besar fotosintat bukan digunakan untuk pertumbuhan vegetatif melainkan untuk mendukung pertumbuhan buah karena buah merupakan komponen terbesar tanaman dibandingkan dengan komponen lain seperti dilaporkan oleh Mattos Jr. et al., (2003).

Tabel 3. Pengaruh Aplikasi Pupuk ZK dan Polyhalite terhadap Pertambahan Panjang Cabang, Kandungan Hara Daun, dan Indeks Klorofil Daun Jeruk Siam

\begin{tabular}{cccccc}
\hline Perlakuan & $\begin{array}{c}\text { Pertambahan } \\
\text { Panjang Cabang }\end{array}$ & & Kandungan Hara Daun & \multicolumn{2}{c}{$\begin{array}{c}\text { Indeks Klorofil } \\
\text { Daun }\end{array}$} \\
\cline { 3 - 5 } & $(\mathbf{c m})$ & $\mathbf{K}(\%)$ & $\mathbf{M g}(\%)$ & $\mathbf{S ~ ( \% )}$ & \\
\hline T1 & 57 & $0,92 \mathrm{a}$ & $0,29 \mathrm{bc}$ & 0,19 & $76,67 \mathrm{~b}$ \\
T2 & 41 & $0,62 \mathrm{~d}$ & $0,28 \mathrm{c}$ & 0,21 & $77,33 \mathrm{~b}$ \\
T3 & 48 & $0,62 \mathrm{~d}$ & $0,33 \mathrm{abc}$ & 0,19 & $81,33 \mathrm{ab}$ \\
T4 & 55 & $0,67 \mathrm{~cd}$ & $0,35 \mathrm{ab}$ & 0,18 & $83,00 \mathrm{ab}$ \\
T5 & 50 & $0,71 \mathrm{bcd}$ & $0,35 \mathrm{ab}$ & 0,19 & $85,00 \mathrm{ab}$ \\
T6 & 52 & $0,79 \mathrm{abc}$ & $0,37 \mathrm{a}$ & 0,18 & $88,67 \mathrm{a}$ \\
\hline
\end{tabular}

Keterangan: Angka-angka yang diikuti dengan huruf yang sama pada kolom yang sama menunjukkan tidak berbeda nyata menurut uji DMRT pada tingkat kepercayaan 95\%.

Aplikasi polyhalite dan ZK berpengaruh nyata terhadap kadar $\mathrm{K}, \mathrm{Mg}$, dan indeks klorofil daun tetapi tidak berpengaruh nyata terhadap kadar $S$ daun. Kadar $\mathrm{K}$ daun pada aplikasi polyhalite dosis tertinggi (T6) tidak berbeda nyata dengan aplikasi ZK (T1) meskipun kandungan kalium pada perlakuan T6 lebih rendah daripada T1. Penurunan dosis polyhalite diikuti dengan penurunan kadar $\mathrm{K}$ daun yang nyata lebih rendah dibandingkan aplikasi ZK.

Kadar Mg daun yang dihasilkan pada perlakuan T6 $(0,37 \%)$ nyata lebih besar dibandingkan dengan perlakuan T1 $(0,29 \%)$ dan T2 $(0,28 \%)$. Hal ini menunjukkan bahwa aplikasi polyhalite pada dosis T3 T6 mampu menyediakan Mg lebih baik sehingga efektif meningkatkan kadar $\mathrm{Mg}$ daun jeruk. Fenomena ini sejalan dengan hasil penelitian pada tanaman teh yang dilaporkan oleh Tu (2018).

Pemberian ZK dan polyhalite tidak memberikan pengaruh yang signifikan terhadap kandungan $S$ daun. $\mathrm{Hal}$ ini diduga dipengaruhi oleh pengalokasian unsur hara di dalam tanaman. Pertambahan panjang cabang, jumlah buah per pohon, serta bobot panen setahun (Tabel 4) memiliki tren yang berlawanan dengan kandungan $\mathrm{S}$, di mana semakin tinggi pertambahan panjang cabang, jumlah buah per pohon, dan bobot panen setahun, maka kadar $S$ pada daun semakin menurun. Hal ini diduga akibat alokasi unsur $S$ pada cabang dan buah jeruk.

Indeks klorofil daun pada aplikasi polyhalite T6 $(88,67 \%)$ nyata lebih besar dibandingkan dengan hasil yang dicapai pada perlakuan ZK $(76,67 \%)$ maupun polyhalite T2 $(77,33 \%)$. Fenomena ini senada dengan respon tanaman pada parameter kadar $\mathrm{Mg}$ daun. Peningkatan aplikasi polyhalite yang diikuti oleh kadar $\mathrm{Mg}$ daun dan indeks klorofil daun mempertegas bahwa $\mathrm{Mg}$ merupakan unsur penting dalam pembentukan klorofil daun jeruk. Menurut Zekri \& Obreza (2016), Mg merupakan pusat dan memainkan peran penting sebagai aktivator dari beberapa enzim. Magnesium mempengaruhi pergerakan karbohidrat dari daun ke bagian lain tanaman, dan merangsang penyerapan dan transportasi P.

\section{Jumlah Buah, Ukuran Buah, dan Bobot Panen}

Jumlah buah yang dihasilkan pada semua perlakuan tidak berbeda nyata, yaitu antara 285 - 389 buah/pohon dalam setahun (Tabel 4). Hal ini disebabkan proses inisiasi pembentukan organ generatif (bakal bunga) telah dimulai bersamaan dengan pertumbuhan dan 
perkembangan buah pada musim panen sebelumnya sehingga jumlah bunga/buah yang dihasilkan

bergantung pada manajemen kebun pada musim tersebut.

Tabel 4. Pengaruh Aplikasi Pupuk ZK dan Polyhalite terhadap Jumlah Buah, Ukuran Buah, Bobot Panen Per Pohon Jeruk Siam

\begin{tabular}{cccc}
\hline Perlakuan & Jumlah buah/pohon & Diameter buah (mm) & $\begin{array}{c}\text { Bobot panen setahun } \\
\text { (kg/pohon) }\end{array}$ \\
\hline T1 & 349 & $70 \mathrm{a}$ & $66 \mathrm{ab}$ \\
T2 & 285 & $60 \mathrm{c}$ & $45 \mathrm{~d}$ \\
T3 & 338 & $62 \mathrm{bc}$ & $49 \mathrm{~cd}$ \\
T4 & 338 & $68 \mathrm{ab}$ & $55 \mathrm{bcd}$ \\
T5 & 338 & $68 \mathrm{ab}$ & $62 \mathrm{abc}$ \\
T6 & 389 & $72 \mathrm{a}$ & $71 \mathrm{a}$ \\
\hline
\end{tabular}

Keterangan: Angka-angka yang diikuti dengan huruf yang sama pada kolom yang sama menunjukkan tidak berbeda nyata menurut uji DMRT pada tingkat kepercayaan 95\%.

Berbeda dengan jumlah buah, ukuran buah dan bobot panen buah pada aplikasi polyhalite T2 dan T3 nyata lebih rendah dibandingkan dengan aplikasi ZK (T1) dan polyhalite dosis tertinggi (T6). Hal ini menunjukkan bahwa polyhalite pada dosis T2 dan T3 belum cukup untuk mendukung pertumbuhan buah yang dihasilkan tanaman sehingga ukuran dan bobot panen lebih rendah dibandingkan perlakuan T1 dan T6. Peningkatan ukuran dan bobot buah jeruk ini sejalan dengan dosis $\mathrm{K}$ yang diaplikasikan melalui polyhalite dan ZK. Sejalan dengan hasil penelitian ini, Quaggio et al. (2011) melaporkan bahwa aplikasi $\mathrm{K}_{2} \mathrm{O}$ sebanyak $200-$ $270 \mathrm{~kg} / \mathrm{ha}$ dapat meningkatkan kualitas buah dan hasil panen jeruk manis.

Walaupun dosis $\mathrm{K}_{2} \mathrm{O}$ lebih rendah dibandingkan dengan perlakuan T1 dan T6, aplikasi polyhalite pada T5 menghasilkan bobot panen dengan ukuran buah yang tidak berbeda nyata dengan T1 dan T6. Fenomena ini menunjukkan bahwa aplikasi polyhalite pada T5 (1.750 $\mathrm{kg} /$ hektar/tahun) merupakan dosis efektif untuk tanaman jeruk Siam dewasa pada Vertisol yang memiliki status $\mathrm{K}$ dapat ditukar sedang dan $\mathrm{Mg}$ serta $\mathrm{Ca}$ dapat ditukar tinggi.

\section{Kualitas Buah}

Kadar sari buah, padatan total terlarut (PTT), asam total tertitrasi (ATT), dan rasio PTT/ATT termasuk parameter penting yang sering digunakan untuk menentukan kualitas internal buah jeruk. Pengaruh aplikasi polyhalite dan ZK tidak nyata terhadap parameter kualitas buah yang diamati, kecuali PTT (Tabel 5). Semua aplikasi polyhalite, kecuali T2, memiliki PTT lebih besar dibandingkan dengan aplikasi ZK. Nilai PTT yang dicapai pada perlakuan T3 - T6 antara 11,50 $11,93^{\circ} \mathrm{Brix}$, sedangkan pada $\mathrm{T} 1$ sebesar $10,55^{\circ}$ Brix. Peningkatan PTT pada perlakuan polyhalite berkaitan dengan peran $\mathrm{Mg}$ dari polyhalite sebagimana ditunjukkan oleh peningkatan data kadar $\mathrm{Mg}$ daun dan indeks klorofil yang sejalan dengan PTT sari buah jeruk. Peningkatan kadar Mg dan indeks klorofil daun mungkin diikuti oleh peningkatan fotosintesis sehingga karbohidrat dan gula yang terbentuk lebih banyak. Selain itu, Mg juga berperan dalam sintesis sukrosa dan beberapa peneliti melaporkan bahwa aplikasi Mg dapat meningkatkan PTT sari buah jeruk (Cakmak \& Yazici, 2010; Fujii et al., 2010; Nasreen et al., 2013; Quaggio et al., 1992).

Tabel 5.Pengaruh Aplikasi Pupuk ZK dan polyhalite terhadap Kadar Sari Buah, Padatan Total Terlarut (PTT), dan Asam Tertitrasi (ATT) pada Buah Jeruk Siam

\begin{tabular}{ccccc}
\hline Perlakuan & Kadar Jus (\%) & PTT ( ${ }^{\circ}$ Brix) & ATT (\%) & PTT/ATT \\
\hline T1 & 37,33 & $10,55 \mathrm{~b}$ & 5.15 & 2,19 \\
T2 & 39,33 & $11,20 \mathrm{ab}$ & 4,88 & 2,34 \\
T3 & 41,67 & $11,83 \mathrm{a}$ & 4,67 & 2,29 \\
T4 & 41,00 & $11,48 \mathrm{a}$ & 3,74 & 3,07 \\
T5 & 40,33 & $11,50 \mathrm{a}$ & 4,56 & 2,52 \\
T6 & 39,33 & $11,93 \mathrm{a}$ & 4,14 & 2,88 \\
\hline
\end{tabular}

Keterangan: Angka-angka yang diikuti dengan huruf yang sama pada kolom yang sama menunjukkan tidak berbeda nyata menurut uji DMRT pada tingkat kepercayaan 95\%.

Walaupun tidak signifikan, kadar ATT pada perlakuan $\mathrm{T} 1(5,15 \%)$ relatif lebih besar dibandingkan dengan hasil yang dicapai pada perlakuan T2 - T6 $(3,74$ - 4,88\%). Secara relatif, peningkatan dosis polyhalite (T2 - T6) diikuti oleh peningkatan PTT dan penurunan kadar ATT sehingga rasio PTT/ATT relatif meningkat dan sebaliknya pada perlakuan T1 (ZK). Rasio PTT/ATT pada T2 - T6 antara 2,34 - 2,88 sedangkan pada T1 sebesar 2,19 (Tabel 5).

\section{KESIMPULAN}

Aplikasi polyhalite menghasilkan kadar $\mathrm{Mg}$ daun, indeks klorofil daun, dan PTT sari buah jeruk Siam lebih tinggi dibandingkan dengan ZK. Pertambahan panjang cabang, kadar $\mathbf{S}$ daun, jumlah buah, kadar jus, serta keasaman jus tidak dipengaruhi oleh penambahan polyhalite. Dosis efektif polyhalite untuk tanaman jeruk Siam dewasa di Vertisol yang berstatus K sedang serta
Ca dan Mg tinggi adalah 2,8 kg/pohon $(1.750 \mathrm{~kg} /$ hektar $)$ setahun diaplikasikan sebanyak 3 kali.

\section{UCAPAN TERIMA KASIH}

Penelitian ini dilaksanakan dalam skema kerja sama antara Balai Penelitian Tanaman Jeruk dan Buah Subtropika dengan PT Wilmar Chemical Indonesia tahun 2019 dengan nomor kontrak B-1453/HK.220/H.3.4/09/2018. Ucapan terima kasih disampaikan kepada Agus Surya Dirawanto atas bantuan teknis di lapangan.

\section{DAFTAR PUSTAKA}

Balai Penelitian Tanah. (2009). Petunjuk Teknis Analisis Kimia Tanah, Tanaman, Air, dan Pupuk (B. H. Prasetyo, D. Santoso, \& L. R. Widowati (eds.); 2nd ed.). Balai Penelitian Tanah.

Barbier, M., Li, Y. C., Liu, G., He, Z., Mylavarapu, R., \& Zhang, S. (2017). Characterizing polyhalite plant 
nutritional properties. Agricultural Research \& Technology: Open Access Journal, 6(3), 65-73. https://doi.org/10.19080/ARTOAJ.2017.06.555690

Boughalleb, F., Mhamdi, M., \& Hajlaoui, H. (2011). Response of young citrus trees to NPK fertilization under greenhouse and field conditions. Agricultural Journal, $6(3)$,

66-73. https://doi.org/10.3923/aj.2011.66.73

Cakmak, I., \& Yazici, A. M. (2010). Magnesium: a forgotten element in crop production. Better Crops, 94(2), 23-25.

Chen, P., \& Wang, L. (2006). Effects of sulfur deficiency on photosynthesis and chlorophyll fluorescence of Citrus sinensis Osbeck leaves. Chinese Journal of Ecology, 5.

Dal Molin, S. J., Nascimento, C. O., Teixeira, P. C., \& De Melo Benites, V. (2019). Polyhalite as a potassium and multinutrient source for plant nutrition. Archives of Agronomy and Soil Science, 00(00), 1-12. https://doi.org/10.1080/03650340.2019.1631451

Farhat, N., Elkhouni, A., Zorrig, W., Smaoui, A., Abdelly, C., \& Rabhi, M. (2016). Effects of magnesium deficiency on photosynthesis and carbohydrate partitioning. Acta Physiologiae Plantarum, 38, 145. https://doi.org/10.1007/s11738-016-2165-z

Fujii, S., Hayashi, T., \& Mizuno, K. (2010). Sucrose synthase is an integral component of the cellulose synthesis machinery. Plant and Cell Physiology, 51(2), 294-301. https://doi.org/10.1093/pcp/pcp190

Koo, R. C. J. (2015). Potassium Nutrition of Citrus. In R. D. Munson (Ed.), Potassium in Agriculture (pp. 1077-1086). American Society of Agronomy, Inc., Crop Science Society of America, Inc., Soil Science Society of America, Inc. https://doi.org/10.2134/1985.potassium.c46

Mattos Jr., D., Quaggio, J. A., Cantarella, H., \& Alva, A. K. (2003). Nutrient content of biomass components of Hamlin sweet orange trees. Scientia Agricola, 60(1), 155-160. https://doi.org/10.1590/S010390162003000100023

Moss, G. I., \& Higgins, M. L. (1974). Magnesium influences on the fruit quality of sweet orange (Citrus sinensis L. Osbeck). Plant and Soil, 41, 103-112.

Nasreen, S., Ahmed, R., Ullah, M. A., \& Hoque, M. A. (2013). Effect of N, P, K, and Mg application on yield and fruit quality of mandarin (Citrus reticulata). Bangladesh Journal of Agricultural Research, 38(3), 425-433.

Obreza, T. A. (2003). Importance of potassium in a Florida citrus nutrition program. Better Crops, 87(1), 60-63.

Obreza, T. A., Rouse, R. E., \& Morgan, K. T. (2008). Managing phosphorus for citrus yield and fruit quality in developing orchards. HortScience, 43(7), 21622166. https://doi.org/10.21273/hortsci.43.7.2162

Paramasivam, S., Alva, A. K., Hostler, K. H., Easterwood, G. W., \& Southwell, J. S. (2000). Fruit nutrient accumulation of four orange varieties during fruit development 1. Journal of Plant Nutrition, 23(3), 313-327.

https://doi.org/10.1080/01904160009382018
Quaggio, J. A., Mattos Jr., D., \& Boaretto, R. M. (2011). Sources and rates of potassium for sweet orange production. Scientia Agricola, 68(3), 369-375. https://doi.org/10.1590/S0103-90162011000300015

Quaggio, J. A., Sobrinho, J. T., \& Dechen, A. R. (1992). Magnesium influences on fruit yield and quality of "Valencia" sweet orange on Rangpur Lime. Proceedings of the International Society for Citriculture, 2, 633-637.

Singh, A., Bakshi, M., Brar, A. S., \& Singh, S. K. (2019). Effect of micro-nutrients in Kinnow mandarin production: A review. International Journal of Chemical Studies, 7(3), 5161-5164.

Suntari, R., Sutopo, \& Maudyansa, A. G. (2020). Pengaruh aplikasi pupuk polyhalite dan $\mathrm{KCl}$ terhadap kadar $\mathrm{K}$ dan pertumbuhan bibit tanaman jeruk pamelo (Citrus maxima) di Kebun Percobaan Balitjestro, Batu. Jurnal Tanah Dan Sumberdaya Lahan, 7(1), 87-92. https://doi.org/10.21776/ub.jtsl.2020.007.1.11

Sutopo, Supriyanto, A., Suhariyono, Setiono, \& Susanto, D. A. (2004). Pendugaan kebutuhan pupuk N, P, dan $\mathrm{K}$ berdasarkan pada panen buah pada jeruk keprok siam. Prosiding Seminar Jeruk Siam Nasional, 280287.

Tränkner, M., Tavakol, E., \& Jákli, B. (2018). Functioning of potassium and magnesium in photosynthesis, photosynthate translocation and photoprotection. Physiologia Plantarum, 163, 414-431. https://doi.org/10.1111/ppl.12747

Tu, T. C. (2018). Effect of polyhalite on tea productivity and quality on basaltic soil in Lam Dong, Vietnam. International Journal of Science and Research, 7(1), 832-834. https://doi.org/10.21275/ART20179475

Yermiyahu, U., Zipori, I., Faingold, I., Yusopov, L., Faust, N., \& Bar-Tal, A. (2017). Polyhalite as a multi nutrient fertilizer-potassium, magnesium, calcium and sulfate. Israel Journal of Plant Sciences, 64, 145157. https://doi.org/10.1163/22238980-06401001

Zekri, M., \& Obreza, T. (2013a). Magnesium (Mg) for citrus trees. UF/IFAS Electronic Data Information Source, SL380.

Zekri, M., \& Obreza, T. (2013b). Potassium (K) for citrus trees. UF/IFAS Electronic Data Information Source, SL381.

Zekri, M., \& Obreza, T. (2019). Calcium (Ca) and sulfur (S) for citrus trees. UF/IFAS Electronic Data Information Source, 7(SL382).

Zekri, M., \& Obreza, T. A. (2002). Plant nutrients for citrus trees. UF/IFAS Electronic Data Information Source, SL200.

Zekri, M., \& Obreza, T. A. (2003). Macronutrient deficiencies in citrus: calcium, magnesium and sulfur. UF/IFAS Electronic Data Information Source, 3(SL202). 